\title{
With thanks to the many individuals who provided their time and expertise to review manuscripts over the past four issues.
}

- Sonia Acorn

University of British Columbia

- Sandra Bassendowski

University of Saskatchewan

- Pamela Baxter

McMaster University

- Mary Agnes Beduz

Mount Sinai Hospital

- Lois Berry

University of Saskatchewan

- Helga Bryant

Norman Regional Health Authority

- Vanessa Burkoski

London Health Sciences

- Heather Campbell

St. Michael's Hospital

- Leigh Chapman

Vancouver Health Authority

- Lynn Digney Davis

Saskatchewan Ministry of Health

- Gail Donner

Donner Wheeler

- Diane Doran

University of Toronto

- Elsie Duff

University of Manitoba
- Karen Eisler

Saskatchewan Registered

Nurses' Association

- Jayne Elliot

University of Ottawa

- Rosmin Esmail

Alberta Health Services

- Helen Ewing

A. T. Still University

- Joan Finegan

Western University

- Kim Fraser

University of Alberta

- Candy Garossino

Providence Health Care

- Wendy Gifford

University of Ottawa

- Esther Green

Cancer Care Ontario

- Noorjean Hassam

BC Cancer Agency

- Rosemary Herbert

University of Prince Edward Island

- Pam Hubley

The Hospital for Sick Children 
- Tina Hurlock-Chorostecki

St. Joseph's Health Centre

- Elsa Jordaan

University of Johannesburg

- Lori Lamont

Winnipeg Regional Health Authority

- Sara Lankshear

Releve Consulting

- Jaime Lapeyre

University of Toronto

- Martha MacLeod

University of Northern British Columbia

- Patricia Malloy

The Hospital for Sick Children

- Patricia Martin-Daniel

George Brown College

- Mary McAllister

Bridgepoint Health

- Kathy McGilton

University Health Network

- Beverley Mclsaac

Association of Registered Nurses of Newfoundland and Labrador

- Carol McNair

The Hospital for Sick Children

- Mary Jane McNally

University Health Network

- Rachel Meyer

University of Toronto

- Barbara Mildon

Ontario Shores

- E. Ann Mohide McMaster University

- Brenda Nevidjon Duke University

- Mary 0’Keefe-Robak New Brunswick Department of Health

- Pammla Petrucka University of Saskatchewan
- Joy Richards

University Health Network

- Carol Ringer

HCPC Canada

- Tiziana Rivera

York Central Hospital

- Don Rose

Ryerson University

- Marcy Saxe-Braithwaite

Western Management Consultants

- Sylvia Scott

Guelph Family Health Team

- Loretta Secco

University of New Brunswick

- Anne Marie Shin

Baycrest Centre for Geriatric Care

- Corey Sigurdson

College of Registered Nurses

of Manitoba

- Beverley Simpson

Beverley Simpson Associates

- Roy Simpson

Cerner

- Cynthia Struthers

University of Toronto

- Rani Srivastava

Centre for Mental Health and Addiction

- Lynn Stevenson

Vancouver Island Health Authority

- Pamela Thorsteinsson

Fraser Health

- Sonia Udod

University of Saskatchewan

- Nancy Walton

Ryerson University

- Carol Wong

Western University 


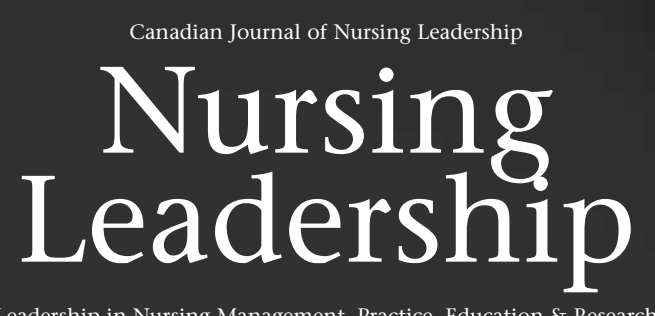

\section{Coming Spring 2013}

\section{A Special Issue of Nursing Leadership}

Migration and Mobility: Informing Nursing Health Human Resources Retention and Recruitment Policy

\section{Articles include:}

Stemming the Flow of Canadian Nurse Migration to the US Linda McGillis Hall et al.

The Experiences of CanadianEducated Early Career Nurses Who Practise in the US Jessica Peterson et al.

I Was Never Recruited:

Challenges in Cross-Canada Nurse Mobility

Linda McGillis Hall et al.

Mapping Nurse Mobility

in Canada with GIS: Career

Movements from Two

Canadian Provinces

Gavin Andrews et al.

Support and Access for Nursing Continuing Education in Canadian Work Environments Michelle Lalonde et al.
Factors That Influence Career Decisions in Canada's Nurses Sheri Price et al.

LPN Perspectives on Factors that Impact Nurse Mobility in Canada Alexandra Harris et al.

Global Trends, Local Impact: The New Era of Skilled Worker Migration and the Implications for Nursing Mobility

Sioban Nelson

Migration and Mobility:

Informing Nursing Health

Human Resources Retention and Recruitment Policy Barbara Foster et al.

Sign up to be alerted when the issue goes online at www.longwoods.com/newsletters 